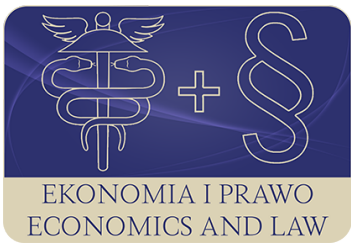

EKONOMIA I PRAWO. ECONOMICS AND LAW

Volume 15, Issue 3, September 2016

p-ISSN 1898-2255, e-ISSN 2392-1625

www.economicsandlaw.pl

EKONOMIA I PRAWO
ECONOMICS AND LAW

ORIGINAL ARTICLE

received 21.10.2015; revised 19.06.2016; accepted 30.09.2016

Citation: Fiedorczuk, M., \& Grabowiecki, J. (2016). Economic and financial crises and changes in corporate governance in Russia (Part 2). Ekonomia i Prawo. Ecomomics and Law, 15(3): 307-316. doi:10.12775/EiP.2016.020.

\title{
Economic and financial crises and changes in corporate governance in Russia (Part 2)
}

\author{
MONIKA FIEDORCZUK \\ corresponding author \\ University of Białystok, Faculty of Economics and Management, Department of International \\ Economic Relations, ul. Warszawska 63, 15-204 Białystok, Poland \\ $\square$ monika.fiedorczuk@uwb.edu.pl

\section{JERZY GRABOWIECKI} \\ University of Białystok, Faculty of Economics and Management, Department of International \\ Economic Relations, Poland \\ $\square$ j.grabowiecki@uwb.edu.pl
}

\begin{abstract}
Motivation: Favourable conditions for the development of corporate governance in Russia emerged at the beginning of the 90s, together with the commencement of economic and political transformation. At the beginning, one of the main factors connected with building and developing a corporate governance system was the process of privatization of state-owned enterprises. In the subsequent years, more factors emerged, such as: further economic reforms, political transformations, corporate legislation as well as financial and economic crises.

Aim: The article's main thrust is to evaluate the impact of economic and financial crisis of 2008 and the posible impact of actual crisis on the evolution of selected internally and externally mechanisms of corporate governance in Russia.

Results: The article uses theoretical analysis method based on a survey of literature and statistical data (especially from Russian Federal Statistics Service). The authors assume that the 2008 crisis caused less significant changes in the process of the evolution of corporate governance system in Russia (in comparison with 1998 crisis). The crisis of 2008 resulted mainly in the increase in the state's role, either as the owner as well as participant of the external corporate governance mechanisms. The impact of the current crisis
\end{abstract}


on the corporate governance is possible because of restrictions in the access to foreign financial markets for big companies and the increase of dependence on financial support from the state.

Keywords: ownership structure; state; corporate control; economic and financial crises JEL: G32; G34

\section{Introduction}

The analysis of changes in the Russian economy from the late 80s of the XX century until now enables the distinction of the main stages of economic transformation as well as the formation of the corporate governance system. The authors claim that economic and financial crises were the key contributors to the transformation of the corporate governance system in Russia. They invoked changes in many supervisory mechanisms. The financial crisis of 1998 began a new stage of ownership redistribution in the Russian corporate sector. Additionally, the crisis of 2008 brought significant increase to the state's role in the corporate governance system either as the owner and participant of the capital market, which had already begun in the middle of the previous decade. The Russian economy faced the crisis also in 2014. The still open question is how it is going to influence the evolution of the corporate governance system.

The main aim of the article is to analyse the impact of economic crisis of 2008 on the changes in the selected corporate governance mechanisms in Russia and the potencial influence of actual crisis on corporate governance.

\section{The state of knowledge - economic crisis of 2008}

In the first months of 2008, either in the global and Russian economy, certain factors emerged, which caused the financial and economic crisis. Among the main reasons for the crisis, which inflicted the Russian economy in 2008, were: external causes - specific problems of the US economy; system causes fundamental problems of the current economic development of the countries; as well as specific Russian circumstances (May, 2010, pp. 86-89). Among some of the internal causes of the Russian crisis, there are: a considerable rise of the stock market indices with relatively low level of capital market development, small diversification of export and economic structure (the dominance of natural resources), which caused a significant dependence of the balance of payment from the cyclicality on international markets, as well as a quick increase in external debt of Russian corporations.

The Russian crisis took three stages. In the first one - the pre-crisis stage - the external factors were revealed, which led to the emergence of negative trends in the Russian economy (financial crisis in Unites States and other developed economies, the massive outflow of foreign capital from Russia). In the second stage, the main impulse for the development of the crisis was 
the adaptation of the Russian economy to the fast deterioration of international economic situation. The outflow of foreign capital from Russia (in September and October, about 84.3 bln USD in total) quickly deteriorated the situation in the field of the balance of payment and the banking system. The result was, among others, the decrease in the ruble exchange rate. Simultaneously, the crisis in the real economy began. The shrinkage of the natural raw materials markets and the drop in their international prices, very quickly caused the crisis in the export oriented Russian sectors. The third stage of the crisis began in November 2008. Its main manifestation was an active focus on combating the crisis of monetary policy means. The interest rate was increased, which caused the reduction of Russian bank lending, especially short-term loans (Белоусов, 2010, pp. 27-29).

Russia belonged to the group of countries, which were inflicted with the crisis to a relatively greatest extent (Кудрин \& Сергиенко, 2011, p. 4). While in 2009, the global Gross Domestic Product (GDP) decreased by $0.6 \%$ compared to the previous year, the Russian GDP decreased as much as 7.8\% (chart 1). The greatest drop concerned the foreign trade turnover - in 2009 it dropped by $35 \%$ compared to the previous year. It was caused mainly by the decrease of crude oil price and oil export revenues (from 151.7 to 93.5 bln USD) (Konończuk, 2012, p. 10).

On the turn of 2008 and 2009, certain anti-crisis solutions were adopted in Russia, including among others: granting financial help for banks; using the resources from the Reserve Fund and the National Welfare Fund in order to prevent a drop in the ruble exchange rate and to reduce the tax pressure on enterprises; conducting a controlled devaluation of the ruble (Institute for the Economy in Transition, 2009, pp. 19-22 and 396-399). The adopted measures did not fully prevent negative trends in the Russian economy, which could be seen in the deterioration of basic macroeconomic indices as well as in the standard of living of the society. They contributed, however, to overcoming these trends. As early as in 2009, there were signs of improvement (among others, the increase in GDP, stabilization of industrial production) (Белоусов, 2010, pp. 31-32).

\section{The methodology of research}

The period of analysis is 2008-2015, from the begininig of the 2008 financial and economic crisis until actual economic crisis in Russian economy. The paper uses the method of analysis of both the scientific literature and the statistical data. To achieve the goal formulated in the article, the comprehensive and critical literature studies and an analysis of statistical data was conducted.

The research was conducted, most of all, on the basis of the analyses performed by the leading Russian research centers, including Institute for Industrial and Market Studies (Higher School of Economics in Moscow), Gaidar Institute for Economic Policy in Moscow, Russian Economic Barometer, National Coun- 
cil of Corporate Governance. Furthermore, the data collected from the Russian Federal State Statistics Service (Rosstat) was used. The article constitutes a part of a broader research project, which aims at characterizing the evolution of the Russian corporate governance system.

\section{The research process and the results of analysis}

\subsection{The impact of the crisis on the corporate governance}

Although the crisis of 2008 significantly influenced the Russian economy, when it comes to main macroeconomic categories, it did not bring any considerable changes in the field of ownership structure of enterprises. According to A. Yakovlev and the co-authors, in most cases the companies preserved the pre-crisis ownership and control structure (Яковлев et al., 2010, p. 31).

Some Russian companies, however, underwent changes which can result in permanent trends in ownership structure in the next few years. From the point of view of many Russian and foreign experts, the second half of the previous decade marked the intensification of the state's role. A. Radygin claims that the trend towards increasing the state's control in the corporate sector of the Russian economy in the years 2007-2008 and after the crisis were stronger than after the crisis of 1998 and at the beginning of the previous decade (Радыгин, 2008, pp. 88-92). According to the Alfa-bank evaluation, part of Russian state-owned companies' shares in 2006 amounted to 29.6\%, at the beginning of $2007-35.1 \%$ and at the beginning of 2008 the ownership concentration of the state, evaluated on the basis of Expert-400 list ${ }^{1}$, reached about $40-45 \%$.

The Rosstat data indicates a rise in the state's participation in the companies' authorized capital — in 2009 it amounted to $42.3 \%$ jointly on every level (when the federal authorities had only $37.8 \%$, chart 2 ). In recent years, this level is standing at over $30 \%$. Moreover, it should be noticed that the presented data can be underestimated. Rosstat publishes the data connected only with the direct ownership and the state-owned companies are treated as private entities. The role of the state has rised because of anti-crisis solution, including launching the public loans program in order to help enterprises repay their foreign debts and making anti-crisis intervention on the capital market, too.

The role of the state as a participant of the capital market should also be highlighted. On the turn of 2008 and 2009, the participation of state-owned enterprises in the value of equity trading turnover was about $51 \%$ (Gaidar Institute for Economic Policy, 2012, pp. 111-112). It was mainly caused by the fact that part of the market participants, due to financial difficulties, came under the control of state banks. In 2011, the participation of state-owned companies

${ }^{1}$ Expert-400 List - ranking of 400 biggest Russian companies according to the level of income, published by the agency RAExpert. 
in equity trading turnover was estimated for about $36 \%$. Among 10 entities with the highest level of capitalization in 2013, in case of the first three the dominant owner was the state. The capitalization of their shares constituted in 2013230.4 bln USD (33.3\% of capitalization of 200 biggest companies in terms of capitalization and about $22 \%$ of the whole equity market capitalization in Russia in 2013) (RAExpert, 2014).

In recent years, the role of the state as a capital market regulator has also been increasing. A legislative function fulfilled in Russia from the beginning of the capital market existence, has been strengthened in recent years by changes in entities responsible for the regulation of market operation. In 2012, the authorities reached a resolution to set up the so-called mega-regulator of the financial market within the structure of the Central Bank of the Russian Federation. The fact that the Central Bank is one of the major participants in the capital market, the shareholder of the Moscow Exchange and the owner of the biggest bank (Sbierbank) triggers a major risk due to a conflict of interest and is a threat for non-state participants of the capital market.

The trends observed after the crisis of 2008 in the Russian banking system could lead to the increase in significance of credit supervision performed by banks in the corporate sector, either in a passive or active dimension. However, those changes have a different character than in the 90s, when the biggest banks were initiating the creation of financial-industrial groups (FIGs) and were also their main entities. In the structure of bank loans, the share of long-term loans is increasing on the scale that was not present in the 90s, which automatically means the necessity of increasing the passive credit supervision and a considerable interest of banks in the efficiency of the credited enterprises. Moreover, bank credits constitute a significant eternal source of financing investment activity of companies (in 2003 over 9\% of participation in the structure of all the sources of investment financing) and they almost 9 times exceed the participation of means from the share issue (Федеральная служба государственной статистики, 2014b).

On the other hand, active credit supervision will demand a deeper study. Some researchers indicate that under conditions of overcoming the crisis of 2008, the Russian banks started active cooperation with their borrowers (Лугачева \& Мусатова, 2010, p. 107). In the second half of 2008, the banks started taking over blocks of shares, which significantly lost on value, as a security for credits. This trend lasted also in 2009 but concerned mainly state-owned banks (among others VTB and Sbierbank) and could be the result of the increasing role of the state in the Russian economy. However, due to the lack of empirical research, it is impossible to clearly state if apart from a greater significance of passive credit supervision, there is also an analogical increase in active supervision. 


\subsection{Economic crisis of 2014-2015 and its potential consequences for corporate governance}

The year 2014 brought the next crisis for the Russian economy. This crisis, according to the researchers, was different from the previous ones and was composed of three elements: structural, economic and external (Улюкаев \& May 2015, pp. 7-8). First of all, it had a structural character because it occurred with the given level of technology and activity of entrepreneurs ${ }^{2}$. Secondly, the crisis is the result of a particular stage of economic cycle and emerges from a slowdown in the pace of investment in authorized capital in the previous years, a decrease in bank loans granted for non-financial sector, rise of 'bad debts' in banks. Thirdly, its causes lie outside the Russian economy and they result from the change in international economic situation and from the breakthrough in the crude oil prices trend. A drop in the price of crude oil (by more than a half, from 110-115 USD for a barrel in the first half of 2014 to 48-49 USD in the selected days from October 2014 to January 2015) led to the decrease in foreign trade participation in GDP. Moreover, the United States and European Union sanctions against Russia were a crisis provoking factor. Currency crisis also appeared simultaneously, reaching the climax stage in December 2014 (drop in the ruble value by about a half).

The main results of sanctions were: intensification of economic and political uncertainty (in two ways - by the decrease in demand that was caused by uncertainty about the future salary as well as by investments - companies are ready to implement only those projects, which guarantee high profitability), restrictions in the transfer of technology, drop in import (it affects mainly those branches, which obtain their components from import), fall in budget transfers (Улюкаев \& May, 2015, p. 8).

At present, generally a great majority of big enterprises was afflicted by restrictions in the access to capital, technology and foreign markets as well as by problems with cooperation with foreign partners in the fields where the sanctions were not imposed directly (Афонцев, 2015, pp. 23-24). As an example, the inflow of capital to Russia in the form of Foreign Direct Investments (FDI) in the first half of 2014 amounted to 22.2 bln USD and in the second half 2.6 bln USD. The outflow of foreign capital in 2014 reached 151 bln compared to 61 bln USD in 2013.

The impact of the current crisis in the Russian economy on the corporate governance system is, as for now, difficult to estimate. However, it is possible to describe main problems that it caused.

Firstly, as the result of the sanctions, the access to foreign financial markets was restricted for big companies. Moreover, the investors started losing confidence, which led to the outflow of foreign capital. On the one hand, companies

2 According to the assessment of the Institute for Economic Policy, the structural pace of increase dropped in Russia from $4-5 \%$ in the previous decade to $1.0-1.5 \%$ in $2014 \mathrm{r}$. In $2015 \mathrm{r}$. the further drop will probably take place. 
will have to act towards improving the standards of corporate governance, especially in the field of protecting the rights and enhancing confidence of private investors. On the other hand, however, these changes may be postponed to more favourable economic period in the future.

For Russian entrepreneurs, it will be necessary to search for new sources of private investment (e.g. as a consequence of initial public offering) and the economy will need the implementation of essential institutional reforms (economic, legal and political) as well as new rules of cooperation with foreign investors - reducing the number of branches where the possibilities of foreign investors activity are limited.

The difficulties in the access to foreign capital for Russian companies can mean the increase of dependence on financial support from the state (Улюкаев \& May, 2015, p. 17). Moreover, the governmental procurements will gain significance when it comes to stimulating the national production. Strong position of the state in the economy, which results from a considerable share in ownership, state's participation in capital market, strong informal relationships between authorities and entrepreneurs, can still be strengthened. The system of corporate governance can therefore evolve towards the system with a considerably significant position of the state.

\section{Conclusion}

The evolution of the corporate governance system in Russia caused that, in Russian companies, there is a dominance of internal supervisory mechanisms, mainly ownership structure, secondary role of external mechanisms, significant role of institutions, formal as well as informal and constantly the same or increasing role of the state within various mechanisms. Those features of corporate governance (besides legal, political and cultural conditions) resulted significantly from financial and economic crises, which had various grounds. The crisis of 1998 was triggered by the lack of financial discipline, soft budget restrictions and was a typical example of a currency crisis. The crisis of 2008 was much more complex and had either internal and external causes. On the one hand, it had a global dimension and in Russia it was only a contagion effect. A drop in global demand meant also a decline in the demand for the main Russian export goods - raw materials. The 2008 crisis highlighted the dependency of Russian economy of oil prices and export revenues.

The crisis of 2008 influenced the change of the particular corporate governance mechanisms to a relatively lesser extent. It resulted in further increase in the state's role as a member of the corporate governance system, either as the owner and participant of the capital market and, on the other hand, in the improvement in the quality of corporate legislation.

The still open question is how the crisis that has been taking place in the Russian economy in recent months will influence the changes in the field of corporate governance. Probably, it will lead to greater enhancement of the state's 
position in the economy. Moreover, the difficulties in the access to the capital on international financial markets should force Russian companies to improve the perception of the corporate governance standards, and, on the other hand, give rise the efforts of government to improve corporate law, law enformcement standards and the other aspect, which could attract foreign capital. It will also be crucial to identify the possible changes in ownership structure, which remains the most important mechanism of corporate governance in the Russian economy. The need to recognize those potential changes will be an important inspiration for further scientific research.

\section{References}

Gaidar Institute for Economic Policy. (2012). Russian Economy in 2011. Trends and Outlooks. Retrieved 15.10.2013 form http://www.iep.ru.

Gaidar Institute for Economic Policy. (2015). Russian Economy in 2014. Trends and Outlooks. Retrieved 08.08.2015 form http://www.iep.ru.

Institute for the Economy in Transition. (2009). Russian Economy in 2008. Trends and Outlooks. Retrieved 10.10.2011 form http://www.iep.ru.

Konończuk, W. (2012). Najlepszy sojusznik Rosji. Kondycja i perspektywy rosyjskiego sektora naftowego, Ośrodek Studiów Wschodnich. Prace OSW, 39.

Афонцев, С. (2015). Выход от кризиса в условиях санкций: миссия невыполнима? Вопросы экономики, 4.

Белоусов, Д.Р. (2010). О развитии кризизса российской экономики в 20082009 гг. Проблемы прогнозирования, 1.

Кудрин, А., \& Сергиенко, О. (2011). Последствия кризиса и перспективы социально-экономического развития России. Вопросы экономики, 3.

Лугачева, Л.И., \& Мусатова, М.М. (2010). Усиление роли государства на рынке слияний и поглощений в период экономической нестабильности. ЭКО, 11.

May, В. (2010). Драма 2008 г.: от „экономического чуда” к экономическому кризису. In Экономика переходного периода. Сборник избранных работ 2003-2009, Retrieved 10.10.2013 form http://www.iep.ru.

Радыгин, А. (2008). Государственный капитализм и финансовый кризис: факторы взаимодействия, издержки и перспективы. Экономическая политика, 6.

RAExpert. (2014). Список крупнейших компаний по рыночной стоимости (капитализации). Retrieved 12.09.2014 form http://raexpert.ru.

Улюкаев, А., \& May, В. (2015). От экономического кризиса к экономическому росту, или как не дать кризису превратиться в стагнацию. Bonpocbl экономики, 4.

Федеральная служба государственной статистики. (2014а). Офищиальная статистика. Retrieved 20.09.2014 from http://www.gks.ru. 
Федеральная служба государственной статистики. (2014b). Предпринимательство, Структура инвестиций в основной капитал по источникам финансирования. Retrieved 04.04.2014 from http://www. gks.ru.

Яковлев, А.А., Данилов, Ю.А., \& Симачев, Ю.В. (2010). Глобальный финансовый кризис и корпоративное управление. Россуйский журнал менеджмента, 8(2).

\section{Acknowledgements}

Author contributions: authors have given approval to the final version of the article. Authors contributed to this work equally.

Funding: this research was fully funded by a grant (DEC-2013/11/N/HS4/03327). 


\section{Appendix}

\section{Chart 1.}

The dynamics of the basic chosen macroeconomic values in Russia in 2003-2014 (in \% compared to the previous year)

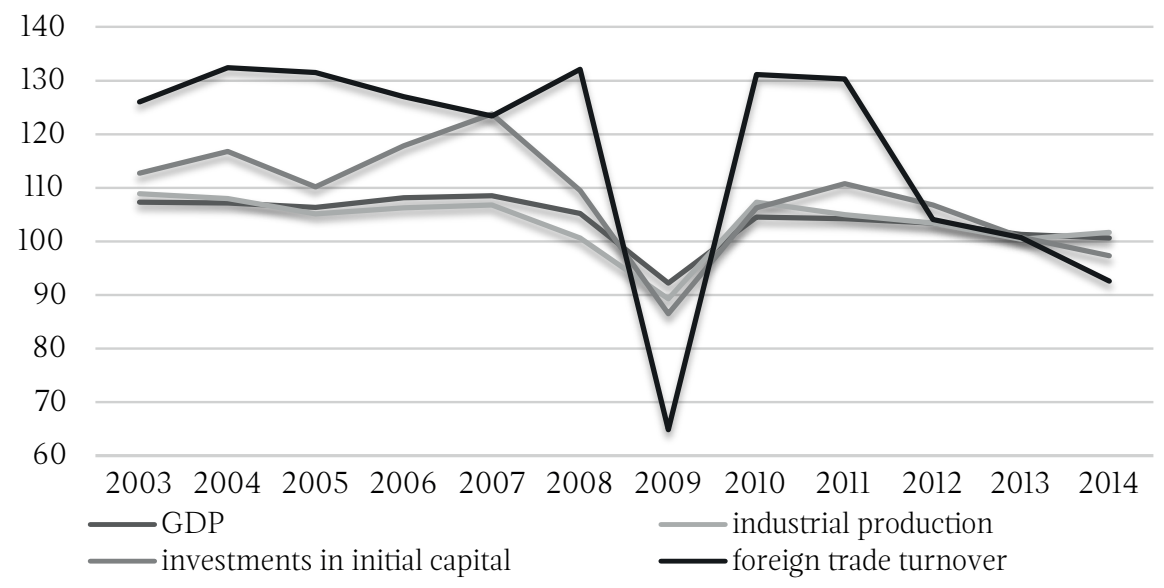

Source: own preparation based on: Федеральная служба государственной статистики (2014a); Gaidar Institute for Economic Policy. (2015, p. 186).

\section{Chart 2.}

The structure of authorized capital of business entities in Russia according to shareholders (founders) in the years 2007-2012 (in \%)

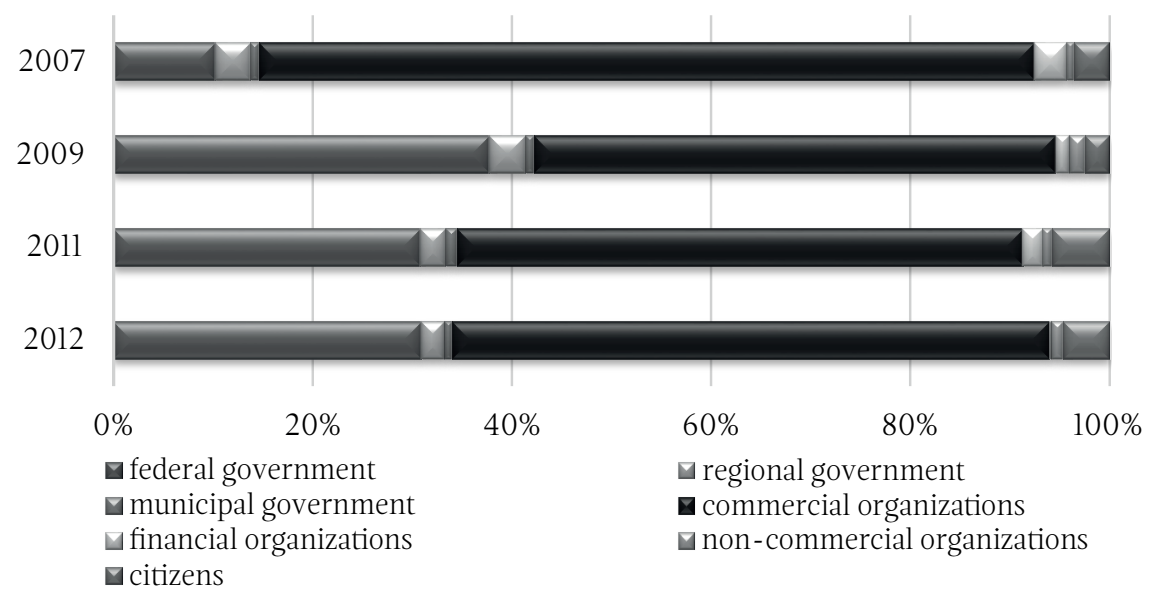

Source: own preparation based on: Федеральная служба государственной статистики (2014b). 